\title{
Embodying the Sacred: Women Mystics in Seventeenth-Century Lima By N. E. van Deusen (2018)
} Durham and London: Duke University Press, viii + 272pp.

Embodying the Sacred is a powerful, mature study about the role materiality, relationality, and politics played in the spiritual life of early modern Lima. Nancy van Deusen's previous works have pointed in this direction, including her edition of Ursula de Jesus' Spiritual Diary (2004), her study of the practice of recogimiento (recollection) as an alternative spiritual institution for early modern women (2002), and her work on sixteenth-century political agency of indigenous people in colonial Spain (2015). She now introduces Lima, one of the two viceregal capitals of the Spanish Empire in the seventeenth-century, through the sensorial and material archives of multiple religious women, considering how they occupied their common space of spiritual, intellectual, and political involvement, while maintaining their ethnic, rank, social, and economic distinctions.

In this book, the author introduces us to the Lima of Rosa, the first American saint, and her disciples, rivals, and generations of followers, women and men, Spaniards, indigenous and of African descent. Drawing on a plethora of records, and confronting legal (Inquisitional) records of spiritual teachings, van Deusen convincingly shows us that 'the seventeenth-century God opened the doors to everyone' (p. 117), and women and other less privileged classes made the best use of this opportunity to advance in perfection through the voices of nuns and other religious women, servants, teachers, students, artisans, and nobles who experienced a mystical relationship with the community and with Divinity.

\section{Affiliation}

TU Chemnitz, Germany.

email: joana.serrado@phil.tu-chemnitz.de 
Van Deusen does not merely describe women's contributions in the history of Christianity, or examine their authority and theological legacy. Rather, the author reflects upon spaces, physical and spiritual, intellectual and sensorial, where gender is seen through the relationship between human beings and God, men and women, women and women, women and objects, objects and rules. With these considerations in mind, van Deusen argues that what lies in the gendering of spaces of seventeenth-century Lima was not so much sexual difference or ethnicity as materiality and relationality.

The first chapter introduces Rosa de Lima (1586-1617, canonized 1671) through the gaze and witness of her disciples. These women participated according to their social and ethnic background. The elite would give alms and organize spaces of devotion, the nuns and nuns-to-be would write down and interpret Rosa's legacy, and those of lower status would clean, care for, and serve Rosa. Nonetheless, they all participated in the same space by listening and reading Rosa's mystical teachings (based on the 'tactile, olfactory and sensory stimulation' of the Divine; p. 36), and by serving as witnesses in the beatification process, which ultimately contributed to Rosa's sanctification and Lima's glorification. The apparently mundane acts of handiwork such as embroidery and sewing, dressing and adorning both themselves and the statues of saintly bodies, or even the mere participation in processions, enunciated an interpretative discourse about Divinity and humanity, and allowed Rosa to engage and teach the mystical body of Christ while participating in the political body of Lima. For the disciples, this became an imitatio morum: imitating Christ through their works, engaging with medieval female saints through the reading of their hagiographies or dressing their statues, or even caring for and venerating the corpse of Rosa.

The second chapter, an adapted version of a 2009 Journal of Religious Studies article, dwells on social and mystical reading practices after Rosa de Lima's sanctification. The author presents the body as a site of spiritual knowledge, which can be actualized, taught, interpreted, and recreated, and which complemented the prevailing reading and aural spiritual practices of the time. After outlining the still prevailing Aristotelian theory of perception and the consequent assertion that women's nature was rendered more susceptible to be called and inspired by God, the author shows how the mystical experience contained empirical and intellective dimensions. Not only would Rosa's followers read and listen to passages about Christ's life and their mystics, but they also actualized this sensory knowledge, through visions, raptures, and supernatural acts. The direct followers and witnesses of Rosa de Lima became themselves some sort of holy

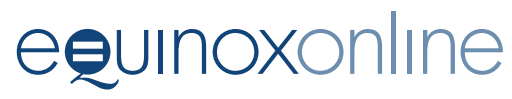


matter for generations to come. The female students accessed the absent voice of Rosa through her direct disciple Isabel de Porras Marmelejo, and artists preserved Marmelejo's bodily transformations through drawings, which were then shared with the wider audience by confessors and priests at public events.

Ángela de Carranza (c. 1642-94), or Mother Ángela de Dios, the mystic who 'frequently ascended to heaven in her undergarments' (p. 86), provides testimony of a colorful and creative theology in the third chapter. Van Deusen examines in detail how Ángela depicted herself - and the people of Lima and other provincial cities perceived her - as Rosa de Lima's extravagant successor. Aided by the Augustinian confessor-scribes who reviewed her 540 notebooks for theological validity, Ángela became a widely popular and sought-after mystic. Her divine knowledge and healing practices extended to the clothes she wore, the objects she touched, and her own bodily parts and fluids. Her socially transverse network of followers (or clients, to use van Deusen's terminology) saw her as a mediator and intercessor for the Divine. In those roles, Ángela actively dismembered and fragmented herself for audience consumption, subject to financial speculation. Nevertheless, it is the same materiality that both makes Ángela famous and condemns her. The body here is a living reliquary that drew the wrath of the whole city when she was forced to accept her deception, in order to escape harsher punishment than imprisonment.

In Chapter 4, van Deusen shifts her focus from materiality to relationality. Through a prosopographical study analyzing the entrance petitions, profession documents, and notarial sources alongside spiritual recollections provided by Ursula de Jesus (1604-88), the author depicts the daily life of donadas. These were the women who engaged in religious and community service through having been donated to a monastery by themselves or by someone else. This path attracted many free women of indigenous and African descent. In this chapter, van Deusen gives a glimpse into the life of seventeenth-century convents through the economic, social, and affective relationships of a donada toward her superiors (nuns), peers (other donadas), inferiors (servants and slaves), and, no less importantly, God. Despite similar motivations and constraints that were particular to their class, they never constitute a homogeneous group. Studying the donadas positionality shows that women lived in the same gendered space but were not seen as equals. The donadas become a common spiritual and political body, where neither sex nor ethnicity played a special role in establishing a sororal community, but rather their own connections and individual attitudes in facing the religious life.

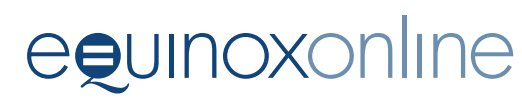


The fate of María Jacinta Montoya and her indigenous husband Nicolás de Ayllón (1632-77) is the subject of the fifth chapter. Here, van Deusen examines the spiritual and political efforts of María Jacinta to simultaneously promote her husband's sainthood and construct her own spiritual identity by mirroring him through a 'Magdalen conversion' (p. 129). Not only did she write and disseminate records detailing her husband's miracles, but she also gathered witnesses and encouraged them to participate in her husband's beatification process, uniting both indigenous and Spanish communities. Moreover, the couple served as an exemplum for indigenous individuals recently converted to Christianity. According to van Deusen, her project not only had an individual and familial-based character, but it also represented efforts to make a more inclusive commonwealth of the Christians in multi-ethnic, seventeenth-century Lima. In this chapter, van Deusen depicts the making of a body painfully aware of the ethnically and gendered constraints in early modern Catholic Lima.

The final chapter deals with the intricate relationship between Josefa Portocarrero Laso de la Vega (1681-1743) and her aristocratic family. Josefa's efforts to enter the newly founded Monastery of Saint Rosa in Lima were hindered by her mother, who filed a legal complaint against her daughter, pointing out her lack of rationality and obedience toward her elders. This legal conflict went beyond a tense mother-daughter relationship, involving Phillip V, the viceroy, and many ecclesiastical authorities. It became instead a philosophical reflection on the limits of freedom of the will and freedom of conscience, as well as family authority and religious obedience. In other words, the struggle Josefa endures reveals the tensions between the spiritual and worldly realm. Van Deusen finishes Lima's portrait as a body that acquires freedom through a spiritual vocation against a background of political and social constraints.

Through such compelling and interconnected biographies, the reader accompanies the characters appearing and reappearing in different lights and perspectives. Nancy van Deusen's style and powerfully creative prose make the characters erupt throughout the narrative, wanting to be seen and heard, and we, the readers, cannot but listen to them and follow them. Rosa de Lima and her rival Ángela de Carranza, the true and the false mystic, respectively, and the generations of their followers to come, reveal the sacralization of a whole urban and cosmopolitan community throughout a century. In this book, van Deusen presents a body that is both mystical and political. The body is presented as a sensorial crux that can be perceived (touched, smelled, tasted, heard, and seen), actualized, rationalized, and even transformed through narratives of interior experiences, and through social, affective, and political relationships throughout multi-ethnic Lima.

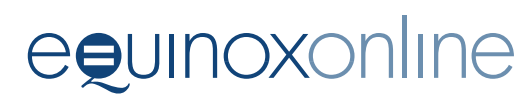




\section{References}

van Deusen, N. E. (2002) Between the Sacred and the Worldly. Palo Alto, CA: Stanford University Press.

van Deusen, N. E. (ed. and trans.) (2004) The Souls of Purgatory: The Spiritual Diary of a Seventeenth-century Afro-Peruvian Mystic, Ursula de Jesús. Albuquerque, NM: University of New Mexico Press.

van Deusen, N. E. (2015) Global índios (Narrating native histories). Durham: Duke University Press. 